\title{
VELOCITY OF POWDER PARTICLES IN PLASMA AT LOW PRESSURE
}

\author{
Mihailo R. Mrdak \\ Research and Development Center IMTEL Communications a.d., \\ Belgrade, Republic of Serbia, \\ e-mail: miki@insimtel.com, \\ ORCID iD: (i)http://orcid.org/0000-0003-3983-1605
}

DOI: 10.5937/vojtehg67-17121; https://doi.org/10.5937/vojtehg67-17121

FIELD: Chemical technology

ARTICLE TYPE: Original scientific paper

ARTICLE LANGUAGE: English

Summary:

Low pressure of inert gas in the vacuum chamber significantly affects the transfer of plasma particle velocity onto powder particles, residence time of powder particles in plasma and the kinetic energy of molten particles before the collision with the substrate. In addition to low pressure of inert gas in the vacuum chamber, the size and mass density of powder particles, together with plasma arc power, have the biggest impact on the average velocity of powder particles. To measure the velocity of powder particles in the vacuum chamber at low pressure, a laser speedometer is applied.The average velocity of molten powder particles $V=s / t$ is calculated when the length of the path of powder particles that pass between two focus distances of the laser beam is divided by the time of particle passage between the two focuses. Measurements are done for vacuum chamber pressure, the values of which are usually from 6.7 to 80 $\mathrm{kPa}$. The paper describes the relationship between the average velocity of $\mathrm{Al}_{2} \mathrm{O}_{3}$ and $\mathrm{W}$ powder particles and the vacuum chamber pressure, granulate distribution, mass density and plasma arc power. It was found that, for powder of lower mass density, the average velocity of particles can increase for $200 \mathrm{~m} / \mathrm{s}$ with a decrease in chamber pressure. The effect of pressure on $W$ particles of larger mass density is lower but still important, because a decrease in pressure increases the average velocity of particles up to $50 \%$. Reducing plasma arc power reduces the maximum velocity of both types of powder particles.

Keywords: VPS, plasma arc power, velocity of powder particles.

ACKNOWLEDGEMENT: The author is thankful for the financial support from the Ministry of Education and Science of the Republic of Serbia (national project Ol 174004, TR 34016). 


\section{Introduction}

The velocity of powder particles is an important variable size of the VPS process which affects particle melting, coating density and cohesive I adhesion strength. When comparing powder deposition at atmospheric pressure with deposition in the environment with reduced pressure, for given arc power and arc gas flow, velocities of plasma particles and powder particles are higher at low pressure than those obtained at atmospheric pressure (Smith \& Dykhuizen, 1988, pp.25-31), (Smith et al, 2011, pp.117-132), (Mrdak, 2018, pp.415-430). Pressure in the vacuum chamber is only one of the variable parameters that affect the velocity of the plasma jet and the velocity of powder particles. The average velocity of powder particles is influenced by several influential variable process values such as: powder mass flow, powder particle size, powder mass density, pressure in the vacuum chamber, plasma arc power, electrode geometry, arc gas flow rate, and plasma gas composition. In order to examine the influence of the process parameters on the velocity of powder particles in the vacuum plasma system applying a laser speedometer, it was found that there is a significant relationship between the velocity of particles and the process parameters such as powder particle size, particle mass density, pressure in the chamber, plasma arc power, and electrode geometry. The laser speedometer method is based on measuring lap times of individual powder particles passing between two highly focused laser beams along the plasma axis (Young et al, 2000, pp.788-792). After the average lap time of molten powder particles is determined, the average particle velocity is calculated based on the known distance between two focal volumes of two laser beams. TwoFocus (L2F) laser with the optical head Polytec model L2F-0-4000 and the signal processor L2F-S-100 is used for measurements (Smith, 1988, pp.77-85), (Mauer et al, 2013, pp.892-900). Within the range of the test conditions, the velocity of powder particles is relatively insensitive to changes in plasma gas velocity, gas composition, and powder flow rate. Today, a large number of powders are deposited at atmospheric pressure, but requests for high-quality coatings have led to the development of powder deposition in the vacuum chamber, which is maintained at a pressure of an inert gas, usually from 1.9 to $6.7 \mathrm{kPa}$ (Muehlberger, 1974, pp.245-256), (Hamatani et al, 2002, pp.79-92). Empirical development of the vacuum deposition process parameters has been successfully carried out for a large number of materials and there are a lot published papers dealing with the fundamental nature of the process of vacuum deposition. Due to the development of nano 
materials deposited in a vacuum using plasma, there is a need for further fundamental research to improve the understanding of physics and thermodynamics of this process. This simultaneously improves equipment construction, coating quality, and reproducibility of coating quality. The vacuum process is today widely used in medicine for the preparation of implants on the basis of nanoparticles of $\mathrm{Ti}, \mathrm{Ta}$, and $\mathrm{Nb}$ metals as well as organic reactive ceramic hydroxyapatite $\mathrm{Ca}_{10}\left(\mathrm{PO}_{4}\right)_{6}\left(\mathrm{OH}_{2}\right)$ and bio inert inorganic ceramics: $\mathrm{Al}_{2} \mathrm{O}_{3}, \mathrm{TiO}_{2}, \mathrm{ZrO}_{2}$, $\mathrm{ZrO}_{2} \mathrm{Y}_{2} \mathrm{O}_{3}$ and $\mathrm{Cr}_{2} \mathrm{O}_{3}$ which have a wide range of applications for the production of the most modern artificial hips and knees (Aebli et al, 2003, pp.356-363), (Zhang et al, 2012, pp.724-728), (Ganvir et al, 2015, pp.324-332), (Graziani et al, 2016, pp.356-363).

The aim of this study was to show and clarify the influence of the variable values of the VPS process on the average velocity value of powder particles in a vacuum. The paper describes the most important parameters in a vacuum affecting the average velocity of $\mathrm{Al}_{2} \mathrm{O}_{3}$ and $\mathrm{W}$ particles for different powder granulations which differ significantly in their mass densities and melting temperatures. $\mathrm{Al}_{2} \mathrm{O}_{3}$ powder has a mass density of $3.95 \mathrm{~g} / \mathrm{cm}^{3}$ and a melting temperature of $2072{ }^{\circ} \mathrm{C}$ while W powder has a mass density of $19.3 \mathrm{~g} / \mathrm{cm}^{3}$ and a melting temperature of $3380^{\circ} \mathrm{C}$. The difference in mass density values is large and is $15.35 \mathrm{~g} /$ $\mathrm{cm}^{3}$ as well as the difference in melting temperatures which is equal to $1308^{\circ} \mathrm{C}$. Based on the above, the paper clearly shows that the pressure values of the vacuum chamber of $80 \mathrm{kPa}, 40 \mathrm{kPa}$ and $6.7 \mathrm{kPa}$ significantly affect the average velocity of powder particles of different granulates and mass densities of powder particles because the pressure in the chamber affects the output velocity and the plasma jet density.

\section{The influence of the pressure in the vacuum chamber on the velocity of powder particles depending on their granulation and mass density}

The optimal VPS parameters are determined for each powder taking primarily into account the average particle size and shape, mass density, and melting temperature. At low pressure, mutual friction between ions and injected particles is necessary to occur for plasma particles to carry powder particles with them. The interaction between ions and powder particles initially accelerates powder particle velocity which increases with the distance from the anode opening. The acceleration of powder particles is directly proportional to the net force in the proper direction and inversely proportional to the mass of particles $\mathrm{a}=\mathrm{F} / \mathrm{m}$. The mass of $\mathrm{a}$ 
particle deposited depends on its size - volume, and its density mass on the base material. Since each powder has a different particle size range, it is necessary to compare powder particle velocities for all powder granulate ranges. $\mathrm{Al}_{2} \mathrm{O}_{3}$ powder with three granulate distributions - 20-31 $\mu \mathrm{m}, 44-63 \mu \mathrm{m}$ and 53-74 $\mu \mathrm{m}$ - has shown to be the most appropriate for analyzing the influence of the particle size range on average particle velocities in plasma. Average particle velocities are measured at several points along the plasma axis in order to compare the velocity profiles for all granulate distributions. The deposition parameters of one type of powder are often used to estimate the parameters of another powder if their mass densities are approximate. Powder mass densities often differ even when other factors (such as particle size, particle morphology, and melting point) are similar. In order to clarify the influence of powder mass density on average powder particle velocities in plasma, the best is to use $W$ with the range of granulation of $44-74 \mu \mathrm{m}$ whose velocity values are comparable to those of average $\mathrm{Al}_{2} \mathrm{O}_{3}$ particle velocities. Tungsten and $\mathrm{Al}_{2} \mathrm{O}_{3}$ represent extremes in mass densities of materials which are often deposited. The $\mathrm{Al}_{2} \mathrm{O}_{3}$ powder density is $3.52 \mathrm{~g} / \mathrm{cm}^{3}$, and the density of $W$ is $19.36 \mathrm{~g} / \mathrm{cm}^{3}$. The pressure in the vacuum chamber significantly affects the powder particles velocity because the pressure in the chamber affects the output velocity and the density of the plasma jet. The profiles of the average velocities for $\mathrm{Al}_{2} \mathrm{O}_{3}$ and $\mathrm{W}$ powders were analyzed in an $\mathrm{Ar} / \mathrm{He}$ plasma jet of a power of $31 \mathrm{~kW}$ for the SG-100 plasma gun with the \# 453 anode at the chamber pressure values of 80 , 40 and $6.7 \mathrm{kPa}$. The powder particles exhibit different velocities depending on granulation, powder types and distances (Smith, 1988, pp.77-85), (Young et al, 2000, pp.788-792).

The comparisons of the average particle velocities of $\mathrm{Al}_{2} \mathrm{O}_{3}$ and $\mathrm{W}$ in Figures 1,2 , and 3 show that the changes in the $\mathrm{Al}_{2} \mathrm{O}_{3}$ particle granulate and in the powder mass density may lead to significant differences in the velocities of particles. At any vacuum chamber pressure, the increase of particle size results in a steady relation with a reduced acceleration / slowdown and lower maximum speeds of particles. The increase of the size and mass of particles results in the increase of the projected area. The mass increase tends to reduce the acceleration / deceleration rate and to lower the maximum speed. Conversely, increasing the surface area tends to increase the force of frontal resistance to particles, which increases the acceleration / deceleration rate as well as the maximum speed. 


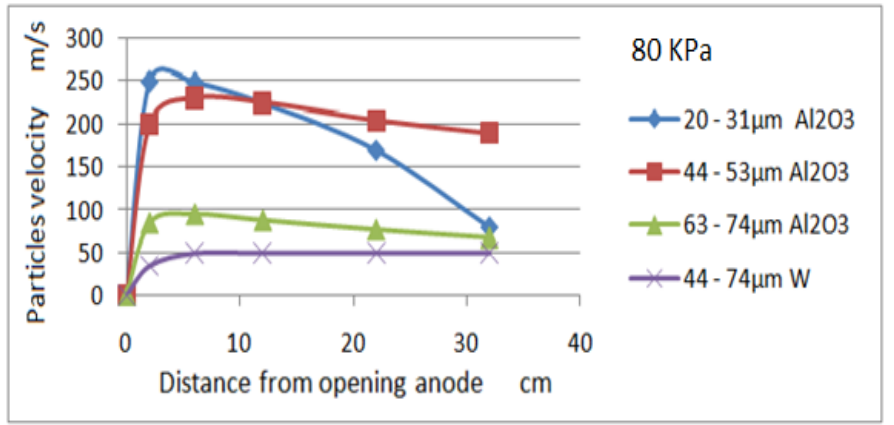

Figure 1 - Average velocities of $\mathrm{Al}_{2} \mathrm{O}_{3}$ and $W$ particles at a pressure of $80 \mathrm{kPa}$

Puc. 1 - Средняя скорость частиц $\mathrm{Al}_{2} \mathrm{O}_{3}$ u W под давлением $80 \mathrm{KPa}$

Слика 1 - Средње брзине честица $\mathrm{Al}_{2} \mathrm{O}_{3}$ u W при притиску од $80 \mathrm{KPa}$

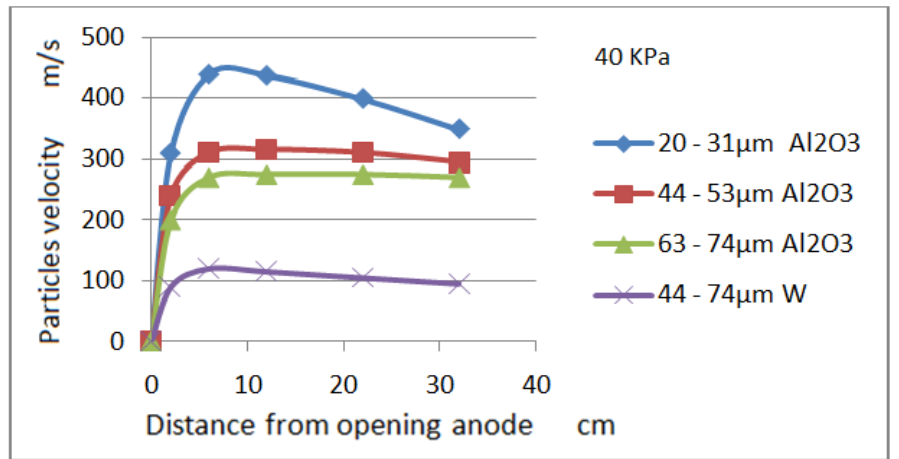

Figure 2 - Average velocities of $\mathrm{Al}_{2} \mathrm{O}_{3}$ and $W$ particles at a pressure of $40 \mathrm{KPa}$

Puc. 2 - Средняя скорость частиц $\mathrm{Al}_{2} \mathrm{O}_{3}$ и W под давлением $40 \mathrm{KPa}$ Слика 2 - Средње брзине честица $\mathrm{Al}_{2} \mathrm{O}_{3}$ u W при притиску од $40 \mathrm{KPa}$

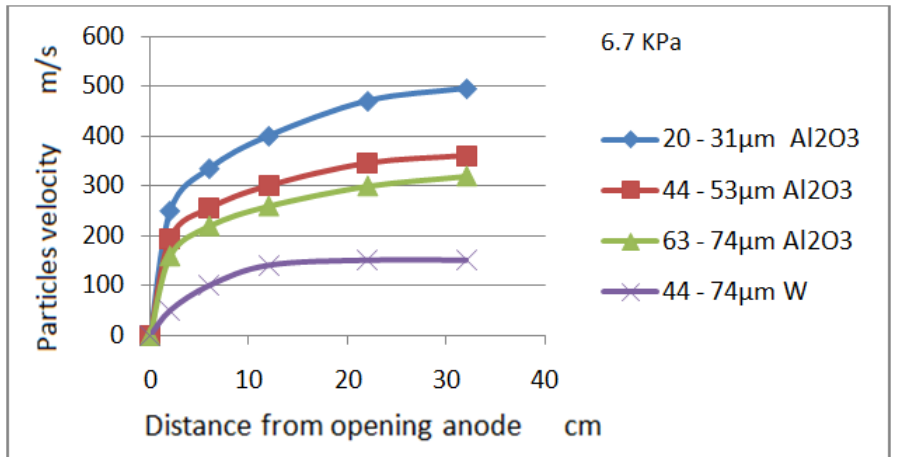

Figure 3 - Average velocities of $\mathrm{Al}_{2} \mathrm{O}_{3}$ and $W$ particles at a pressure of $6.7 \mathrm{KPa}$ Puc. 3 - Средняя скорость частиц $\mathrm{Al}_{2} \mathrm{O}_{3}$ u $W$ под давлением 6,7 Kра Слика 3 - Средње брзине честица $\mathrm{Al}_{2} \mathrm{O}_{3}$ u W при притиску од 6,7 KPa 
For a spherical particle or a molten droplet of the radius $r$, the mass increases as $r^{3}$, but the projected area increases only as $r^{2} . A_{2} \mathrm{O}_{3}$ particles are not spherical, but it is expected that the mass of particles increases faster than the projected area. The impacts of the increasing mass should prevail if the forces of resistance do not increase as a very fast function of the projected surface. The experimental results confirm that the increase in mass is the predominant factor for these three dimensions of $\mathrm{Al}_{2} \mathrm{O}_{3}$ powder, Figures 1,2 and 3 . The same should apply to other materials with a mass density greater than $\mathrm{Al}_{2} \mathrm{O}_{3}$ (Smith, 1988, pp.77-85), (Young et al, 2000, pp.788-792). Larger powder particles are slower and their residence time in plasma is longer although the velocity of plasma particles is higher compared to that of powder particles. The result is a better transfer of heat energy to larger particles which require more energy to be completely moltened. While this is clearly a desirable trend, experience indicates that it is still very difficult to achieve uniform melting of powder with a broad distribution of sizes. Figures 1, 2 and 3 show the results for the sizes 44-74 $\mu \mathrm{m}$ of the $\mathrm{W}$ powder. Based on the above description, more massive tungsten particles show lower acceleration / deceleration velocities and lower maximum velocities compared to lighter $\mathrm{Al}_{2} \mathrm{O}_{3}$ particles of the similar size. If we compare all the results at any given pressure in the vacuum chamber, there is a very obvious progressive trend towards lower, more consistent velocities while increasing the particle mass.

\section{The influence of pressure in the vacuum chamber on} the average velocity of powder particles for a constant range of granulates

The influence of changes in pressure in the vacuum chamber on the average velocity of powder particles with a constant range of granulates is shown in Figures 4, 5 and 6.

These results can be explained on the basis of changes in the velocity and density of the plasma jet related to the pressure, as well as on the basis of the density of the surrounding gas in the vacuum chamber. The exit velocity of the plasma particles from the plasma gun is approximately $1700 \mathrm{~m} / \mathrm{s}$ at an operating pressure of $80 \mathrm{kPa}, 2455 \mathrm{~m} / \mathrm{s}$, at $40 \mathrm{kPa}$, and $3300 \mathrm{~m} / \mathrm{s}$ at $6.7 \mathrm{kPa}$. 


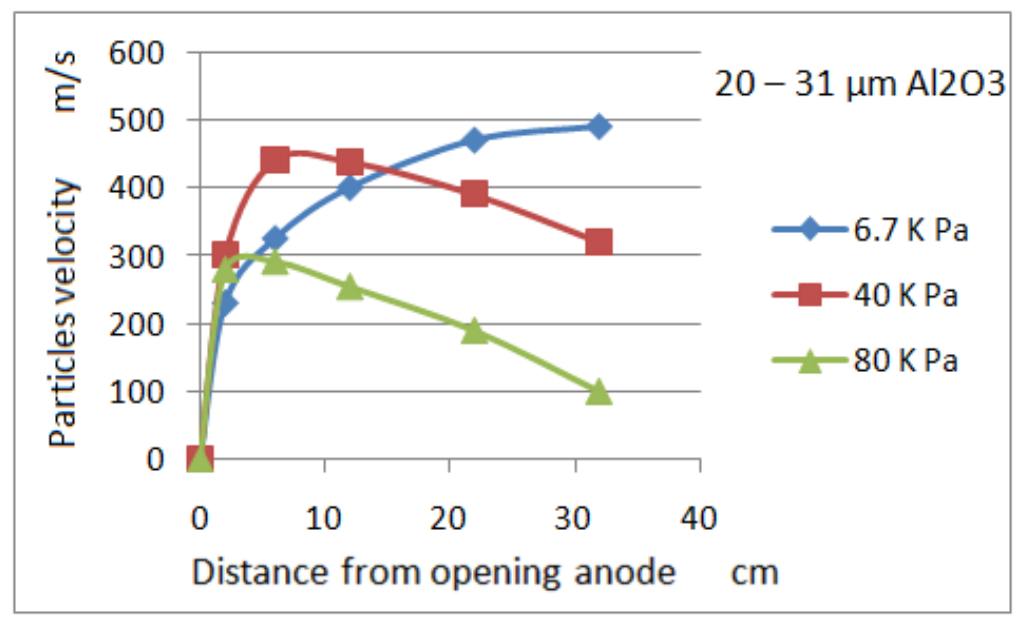

Figure 4 - Average velocities of $\mathrm{Al}_{2} \mathrm{O}_{3}$ particles with a granulation of 20-31 $\mu \mathrm{m}$ with the change of pressure

Puc. 4 - Средняя скорость частиц $\mathrm{Al}_{2} \mathrm{O}_{3}$ грануляции 20-31 нт с изменением давления

Слика 4 - Средње брзине честица $\mathrm{Al}_{2} \mathrm{O}_{3}$ гранулације 20-31 нт при промени притиска

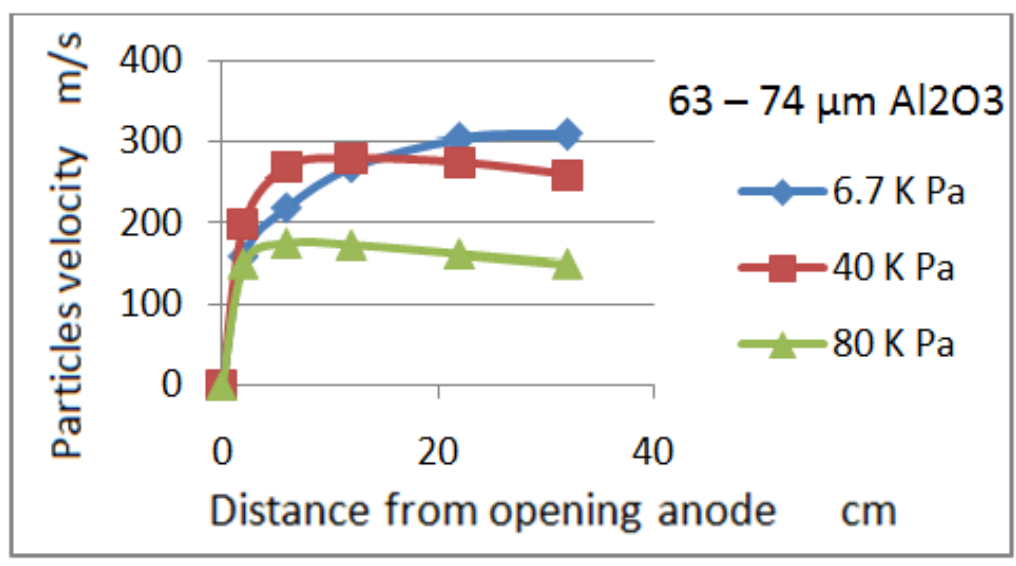

Figure 5-Average velocities of $\mathrm{Al}_{2} \mathrm{O}_{3}$ particles with a granulation of 63-74 $\mu \mathrm{m}$ with the change of pressure

Puc. 5 - Средняя скорость частиц $\mathrm{Al}_{2} \mathrm{O}_{3}$ грануляции 63-74 нт с изменением давления

Слика 5 - Средње брзине честица $\mathrm{Al}_{2} \mathrm{O}_{3}$ гранулације 63-74 $\mu$ при промени притиска 


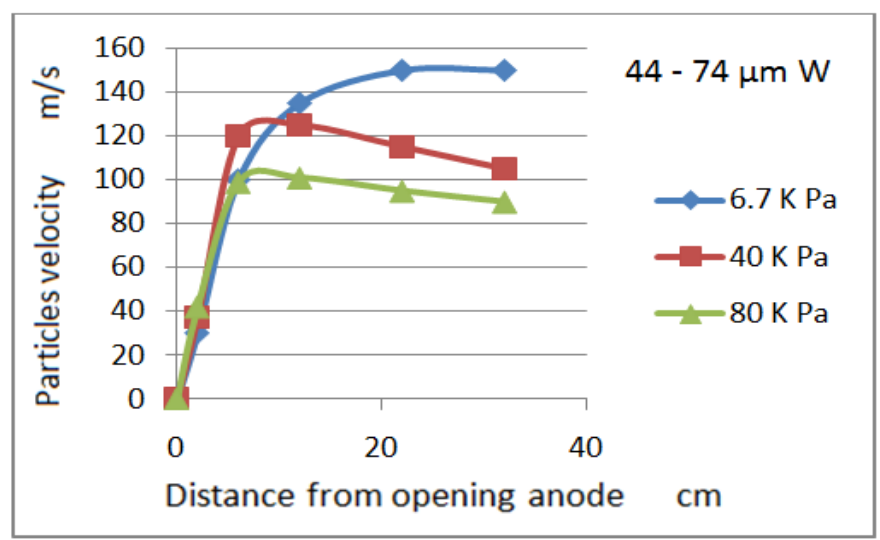

Figure 6-Average velocities of $W$ particles with a granulation of 44-74 $\mu \mathrm{m}$ with the change of pressure

Puc. 6 - Средняя скорость частиц W грануляции 44-74 $\mu$ с с перепадом давления Слика 6 - Средње брзине честица W гранулације 44-74 $\mu т$ при промени притиска

This is in compliance with the results of the average velocities of $\mathrm{Al}_{2} \mathrm{O}_{3}$ and $\mathrm{W}$ powder particles shown in Figures 4, 5 and 6, which show progressively higher maximum powder particle velocity values as the pressure in the chamber decreases (Smith, 1988, pp.77-85), (Young et al, 2000, pp.788-792). Plasma density decreases with the decrease of the pressure in the chamber. Higher plasma velocity in relation to powder particles tends to increase the velocity of particles, but a plasma density decrease has the opposite effect. Based on the net combined impact of these opposing trends, the model predicts that the maximum acceleration of particles occurs at a chamber pressure of $45 \mathrm{kPa}$.

The results shown in the figures support this prediction because the particle velocity is at its highest at the first measuring point of $2.5 \mathrm{~cm}$ at a pressure of $40 \mathrm{kPa}$. The influence of the resistance of the surrounding gas in the vacuum chamber becomes more important with an increasing distance from the nozzle outlet. At lower chamber pressures, the resistance is lower to slow the plasma jet and depositing particles.

Therefore, as the chamber pressure decreases, the particle velocity maxima are moving away from the anode opening and the particle velocity decrease becomes more gradual. The dependence of the mass is also visible in the figures. The same trends associated with the pressure were observed for each of the three powders, but the changes in the average velocity profiles are much bigger for lighter $\mathrm{Al}_{2} \mathrm{O}_{3}$ particles. 


\section{The influence of the plasma arc power and a nozzle type on the average velocity of powder particles in the vacuum chamber}

The geometry of the nozzle - anode affects the exit velocity of the plasma jet. Anode model \# 453 has a divergent part at the nozzle exit designed to produce supersonic flow of plasma at atmospheric pressure. Anode model \# 450 is similar to anode \# 453 with the exception that anode \# 450 is constructed with a simple nozzle with a flat opening for subsonic operation at atmospheric pressure. Although these anodes were originally designed to operate at atmospheric pressure, both work well at low pressure values in the chamber. Since the arc power is easy to control and observe, it is an important variable in the process of optimization of the conditions for depositing powders. The effect of the plasma arc power on the average velocity of particles was investigated by comparing the velocity profiles measured for the power values of 31 kW and 21 kW (Smith, 1988, pp.77-85), (Young et al, 2000, pp.788-792). Figure 7 shows the influence of the plasma arc power on the average velocity for fine $\mathrm{Al}_{2} \mathrm{O}_{3}$ powder particles with the particle size of 20-31 $\mu \mathrm{m}$ and for coarse $\mathrm{W}$ powder particles with the granulation of 44-74 $\mu \mathrm{m}$, injected through anode \# 453 at a chamber pressure of $6.7 \mathrm{kPa}$.

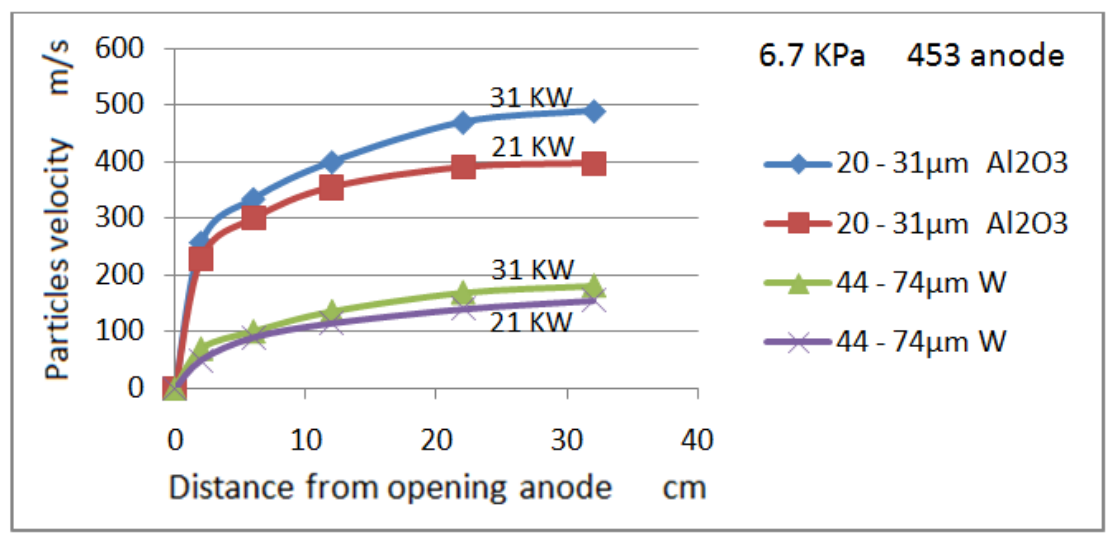

Figure 7 - Influence of the plasma arc power on the average velocities of $\mathrm{Al}_{2} \mathrm{O}_{3}$ and $\mathrm{W}$ particles at $6.7 \mathrm{KPa}$

Puc. 7 - Воздействие силы плазменной дуги на среднюю скорость частиц $\mathrm{Al}_{2} \mathrm{O}_{3} \mathrm{u}$ W на $6.7 \mathrm{KPa}$

Слика 7 - Утицај снаге плазменог лука на средње брзине честица $\mathrm{Al}_{2} \mathrm{O}_{3}$ u W на 6,7 $\mathrm{KPa}$ 


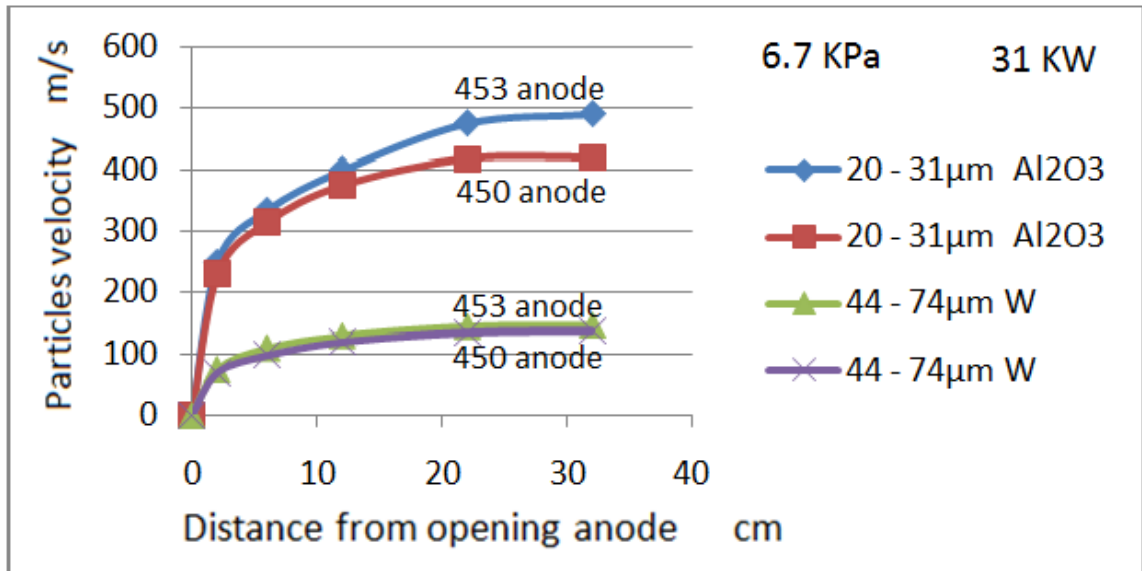

Figure 8-Comparison of the average velocities of $\mathrm{Al}_{2} \mathrm{O}_{3}$ and $\mathrm{W}$ particles sprayed with 453 and 450 anodes at $6.7 \mathrm{KPa}$

Puc. 8 - Сравнение средней скорости частиц $\mathrm{Al}_{2} \mathrm{O}_{3}$ и W с анодным слоем 453 и 450 на $6.7 \mathrm{KPa}$

Слика 8 - Компарација средње брзине честица $\mathrm{Al}_{2} \mathrm{O}_{3}$ u W напрсканих са анодама 453 и 450 на $6.7 \mathrm{KPa}$

Reducing the plasma arc power from 31 to $21 \mathrm{~kW}$ significantly reduces the acceleration and the maximum velocity for both powder types. The actual value of the maximum velocity reduction is higher for $\mathrm{Al}_{2} \mathrm{O}_{3}$ powder and the relative change in velocity is roughly $20 \%$ for both powders. These results show that changes in the plasma arc power can significantly affect the velocity of powder particles, but it is clear that a change of the plasma arc power of only 1 or $2 \mathrm{~kW}$ during depositing will not have a significant impact (Smith, 1988, pp.77-85), (Young et al, 2000, pp.788-792). Figure 8 shows the comparison of the average velocity profiles for fine $\mathrm{Al}_{2} \mathrm{O}_{3}$ powder with a particle size of 20-31 $\mu \mathrm{m}$ and for coarse W powder particles with a granulation of 44-74 $\mu \mathrm{m}$, injected through anodes \# 453 and \# 450 in a pressure chamber of $6.7 \mathrm{kPa}$. Changing the anode resulted in the reduction of the maximum velocity of about $10 \%$ for both powders. The results show that the anode change can also affect the velocity of powder particles.

Different flow rates and gas compositions did not show any significant effects on the velocity of particles within the range of the conditions studied. This is very interesting because these variables can have a significant effect on particle melting and the quality of the deposit. Since most plasma systems are designed to maintain a constant power supply to the plasma arc, it is emphasized that the experiments are 
carried out at constant plasma arc power values. The flow of arc gas and the composition affect the relation of the current and the voltage of the plasma gun. Therefore, changes in the flow rate or in the gas composition will lead to changes in the arc power if the electric current intensity is not adjusted. If the arc power is allowed to vary as a function of the arc gas flow rate or its composition, the particle velocity will be changed as well, as shown in Figure 7(Smith, 1988, pp.77-85), (Young et al, 2000, pp.788-792).

\section{Conclusion}

The paper presents the influence of low pressure in the vacuum chamber and the plasma arc power on the average velocities of $\mathrm{Al}_{2} \mathrm{O}_{3}$ powder particles with different granulation as well as of $\mathrm{W}$ powder particles of extreme mass density. Based on the above, the following has been established.

For the same low pressure in the vacuum chamber, with increasing $\mathrm{Al}_{2} \mathrm{O}_{3}$ granulation, the acceleration and the velocity of powder particles progressively decrease to $200 \mathrm{~m} / \mathrm{s}$. Also, larger $\mathrm{Al}_{2} \mathrm{O}_{3}$ particles are less sensitive to the chamber pressure change from 6.7-80 MPa. Larger powder particles are slower and their residence time in plasma is longer even though the velocities of plasma particles are higher in comparison to powder particles.

W particles of larger mass density are less susceptible to a change in pressure in the vacuum chamber in relation to $\mathrm{Al}_{2} \mathrm{O}_{3}$ particles. However, even $\mathrm{W}$ particles show an increase in the average velocity of powder particles of $50 \mathrm{~m} / \mathrm{s}$ to $150 \mathrm{~m} / \mathrm{s}$ with a reduction in pressure in the chamber from $80 \mathrm{MPa}$ to $6.7 \mathrm{MPa}$. At lower pressure in the chamber, there is less resistance to slow plasma jet and particle deposition. Therefore, when pressure in the chamber decreases, the maximum particle velocities move away from the anode opening and particle deceleration becomes more gradual.

With the decrease of arc power from $31 \mathrm{~kW}$ to $21 \mathrm{~kW}$, it was noticed that acceleration was reduced as well as the maximum particle velocity for both powders. The actual value of the reduction of the maximum velocity is higher for the powder of lower mass density $\left(\mathrm{Al}_{2} \mathrm{O}_{3}\right)$ and a relative change in velocity for both powders is roughly $20 \%$. The results show that a change in the plasma arc power can significantly affect the velocity of powder particles, but it is also clear that a change of plasma arc power of only 1 or $2 \mathrm{~kW}$ during deposition will not have a considerable impact. 
This article has shown that the change of pressure in the vacuum chamber for $\mathrm{Al}_{2} \mathrm{O}_{3}$ and $\mathrm{W}$ powders can lead to a change in the average velocity of powder particles with the plasma spray distance depending on particle granulation distribution and the plasma arc power.

\section{References}

Aebli, N., Krebs, J., Stich, H., Schawalder, P., Walton, M., Schwenke, D., Gruner, H., Gasser, B., \& Theis, J. 2003. In vivo comparison of the osseointegration of vacuum plasma sprayed titanium- and hydroxyapatitecoated implants. Journal of Biomedical Materials Research, 66(2), pp.356-363. Available at: https://doi.org/10.1002/jbm.a.10508.

Ganvir, A., Curry, N., Govindarajan, S., \& Markocsan, N. 2015. Characterization of Thermal Barrier Coatings Produced by Various Thermal Spray Techniques Using Solid Powder, Suspension, and Solution Precursor Feedstock Material. International Journal of Applied Ceramic Technology, 13(2), pp.324-332. Available at: https://doi.org/10.1111/ijac.12472.

Graziani, G., Bianchi, M., Sassoni, E., Russo, A., \& Marcacci, M. 2017. Ionsubstituted calcium phosphate coatings deposited by plasma-assisted techniques: A review. Materials Science and Engineering: C, 74(1), pp.219-229. Available at: https://doi.org/10.1016/j.msec.2016.12.018.

Hamatani, H., Crawford, W., \& Cappelli, M. 2003. Optical measurements of plasma velocity and temperature in a low-rate, low-power LPPS system. Surface and Coatings Technology, 162(1), pp.79-92. Available at: https://doi.org/10.1016/s0257-8972(02)00565-0.

Mauer, G., Vaßen, R., Zimmermann, S., Biermordt, T., Heinrich, M., Marques, J.-L., Landes, K., \& Schein, J. 2013. Investigation and Comparison of In-Flight Particle Velocity During the Plasma-Spray Process as Measured by Laser Doppler Anemometry and DPV-2000. Journal of Thermal Spray Technology, 22(6), pp.892-900. Available at: https://doi.org/10.1007/s11666013-9940-9.

Mrdak, M. 2018. Transfer of heat and speed of plasma particles to powder particles in the plasma spray process at atmospheric pressure. Vojnotehnički glasnik/Military Technical Courier, 66(2), pp.415-430. Available at: https://doi.org/10.5937/vojtehg66-12942.

Muehlberger, E. 1974. A High Energy Plasma Coating Process. In 7th International Metal Spraying Conference, The Welding Institute, Abington, Cambridge, U.K., pp.245-256.

Smith, F.M. 1988. Laser Measurement of Particle Velocities in Vacuum Plasma Spray Deposition. In 1st Plasma - Technik - Symposium, Swicerland, Lucerne, May 18-20, pp.77-85. 
Smith, M.F., \& Dykhuizen, R.C. 1988. Effect of chamber pressure on particle velocities in low pressure plasma spray deposition. Surface and Coatings Technology, 34(1), pp.25-31. Available at: https://doi.org/10.1016/0257-8972(88)90085-0.

Smith, M.F., Hall, A.C., Fleetwood, J.D., \& Meyer, P. 2011. Very Low Pressure Plasma Spray: A Review of an Emerging Technology in the Thermal Spray Community. Coatings, 1(2), pp.117-132. Available at: https://doi.org/10.3390/coatings1020117.

Young, E.J., Mateeva, E., Moore, J.J., Mishra, B., \& Loch, M. 2000. Low pressure plasma spray coatings. Thin Solid Films, 377-378, pp.788-792. Available at: https://doi.org/10.1016/s0040-6090(00)01452-8.

Zhang, N., Zhu, L., Planche, M.P., \& Coddet, C. 2012. In-flight particle characterization and coating formation of yttria-stabilized zirconia under low pressure plasma spray condition. In Thermal Spray: Proceedings from the International Thermal Spray Conference and Exposition, USA, Texas, Houston, May 21-24, pp.724-728.

СКОРОСТЬ ЧАСТИЦ ПОРОШКА В ПЛАЗМЕ ПОД НИЗКИМ ДАВЛЕНИЕМ

Михаило Р. Мрдак

Центр исследований и развития А.О. «ИМТЕЛ коммуникации»,

г. Белград, Республика Сербия

РУБРИКИ: 61.13.21 Химические процессы

ВИД СТАТЬИ: оригинальная научная статья

ЯЗЫК СТАТЬИ: английский

Резюме:

Низкое давление инертного газа в вакуумной камере оказывает значительное воздействие на передачу скорости плазменных частиц на частицы порошка, время нахождения порошка в плазме и кинетическую энергию расплавленных частиц до момента соприкосновения с защитным слоем. На среднюю скорость частиц порошка, кроме низкого давления инертного газа в вакуумной камере наибольшее воздействие оказывает величина и плотность частиц порошка, а также сила плазменной дуги. Для измерения скорости частиц порошка в вакуумной камере под низким давлением используются лазерные измерители скорости. Средняя скорость частиц расплавленного порошка $V=s / t$ рассчитывается, следующим образом: длина пути частии, порошка, прошедших между двумя очаговыми расстояниями лазерного луча делится на время прохождения частиц между двумя фоокусами. Измерение давления производится в вакуумной камере, при давлении, которое чаще всего применяется: от 6,7-80 kPa. В данной работе представлено каким образом давление в 
вакуумной камере, распределение гранулята, плотность и сила плазменной дуги влияют на среднюю скорость частиц порошка $\mathrm{Al}_{2} \mathrm{O}_{3}$ u W. Исследования показали, что скорость частиц порошка с меньшей плотностью может увеличиваться на $200 \mathrm{M} / \mathrm{c}$ при снижении давления в камере. Выявлено, что эффрект давления на частицы с большей плотностью $W$ значительно меньше, хотя он тоже важен, так как при снижении давления увеличивается скорость частиц до 50\%. При уменьшении силы плазменной дуги снижается удельная скорость частиц обоих видов порошков.

Ключевые слова: ВПН, сила, плазменная дуга, скорость частиц порошка.

\section{БРЗИНЕ ЧЕСТИЦА ПРАХА У ПЛАЗМИ НА НИСКОМ ПРИТИСКУ}

Михаило Р. Мрдак

Истраживачки и развојни центар ИМТЕЛ Комуникације а.д., Београд,

Република Србија

ОБЛАСТ: хемијске технологије

ВРСТА ЧЛАНКА: оригинални научни рад

ЈЕЗИК ЧЛАНКА: енглески

Сажетак:

Низак притисак инертног гаса у вакуум-комори знатно утиче на пренос брзине честица плазме на честице праха, време боравка честица праха у плазми и кинетичку енергију истопљених честица пре судара са подлогом. На средњу брзину честица праха, поред ниског притиска инертног гаса у вакуум-комори, највећи утицај има величина и масена густина честица праха и снага плазмалука. За мерење брзине честица праха у вакууму на ниском притиску коморе примењује се ласерски мерач брзине. Средња брзина честица истопљеног праха $V=s / t$ прорачунава се када се дужина пута честица праха које прођу између два жижна одстојања ласерског зрака поделе са временом пролаза честица између две жиже. Мерења се обављају за притисак у вакуум-комори који је најчешће од 6,7 до 80 kPa. У раду је приказана веза између средње брзине честица праха $\mathrm{Al}_{2} \mathrm{O}_{3}$ u W у зависности од притиска у вакуум-комори, расподеле гранулата, масене густине и снаге плазма-лука. Установљено је да се за прах мање масене густине може, уз смањење притиска у комори, повећати просечна брзина честица за $200 \mathrm{~m} / \mathrm{s}$. Ефеекат притиска на честице веће масене густине $W$ је мањи, мада је битан, јер се са смањењем притиска увећава средња брзина честица до 50\%. Смањење снаге плазмалука смањује максималне брзине честица за оба праха.

Кључне речи: ВПС, снага плазма-лука, брзина честица праха. 
Paper received on / Дата получения работы / Датум пријема чланка: 11.04.2018. Manuscript corrections submitted on / Дата получения исправленной версии работы / Датум достављања исправки рукописа: 21.04.2018.

Paper accepted for publishing on / Дата окончательного согласования работы / Датум коначног прихватања чланка за објављивање: 23.04.2018.

(C) 2019 The Author. Published by Vojnotehnički glasnik / Military Technical Courier

(www.vtg.mod.gov.rs, втг.мо.упр.срб). This article is an open access article distributed under the terms and conditions of the Creative Commons Attribution license (http://creativecommons.org/licenses/by/3.0/rs/).

() 2019 Автор. Опубликовано в «Военно-технический вестник / Vojnotehnički glasnik / Military Technical Courier» (www.vtg.mod.gov.rs, втг.мо.упр.срб). Данная статья в открытом доступе и распространяется в соответствии с лицензией «Creative Commons» (http://creativecommons.org/licenses/by/3.0/rs/).

(c) 2019 Аутор. Објавио Војнотехнички гласник / Vojnotehnički glasnik / Military Technical Courier (www.vtg.mod.gov.rs, втг.мо.упр.срб). Ово је чланак отвореног приступа и дистрибуира се у складу са Creative Commons licencom (http://creativecommons.org/licenses/by/3.0/rs/).

(c) (i) 